\title{
Coronary flow reserve correlates with right ventricular dysfunction and predicts right heart failure in patients with pulmonary arterial hypertension
}

Jan Skrok, Monda L Shehata, Stephen Mathai, Miguel Santaularia Tomas, Sukhminder Singh, Reda E Girgis, James O Mudd, Danielle Boyce, Noah Lechtzin, Joao AC Lima, David A Bluemke, Paul M Hassoun, Jens Vogel-Claussen

From 2011 SCMR/Euro CMR Joint Scientific Sessions

Nice, France. 3-6 February 2011

\section{Background}

In pulmonary arterial hypertension (PAH) increased pressure and resistance in the pulmonary vascular bed cause right ventricular (RV) hypertrophy with increased myocardial oxygen demand. Studies in animals with RV hypertrophy demonstrated maintained resting but

reduced stress perfusion and coronary perfusion reserve, which may contribute to RV failure.

\section{Purpose}

The purpose of our study was to investigate myocardial perfusion by comparing coronary sinus flow reserve

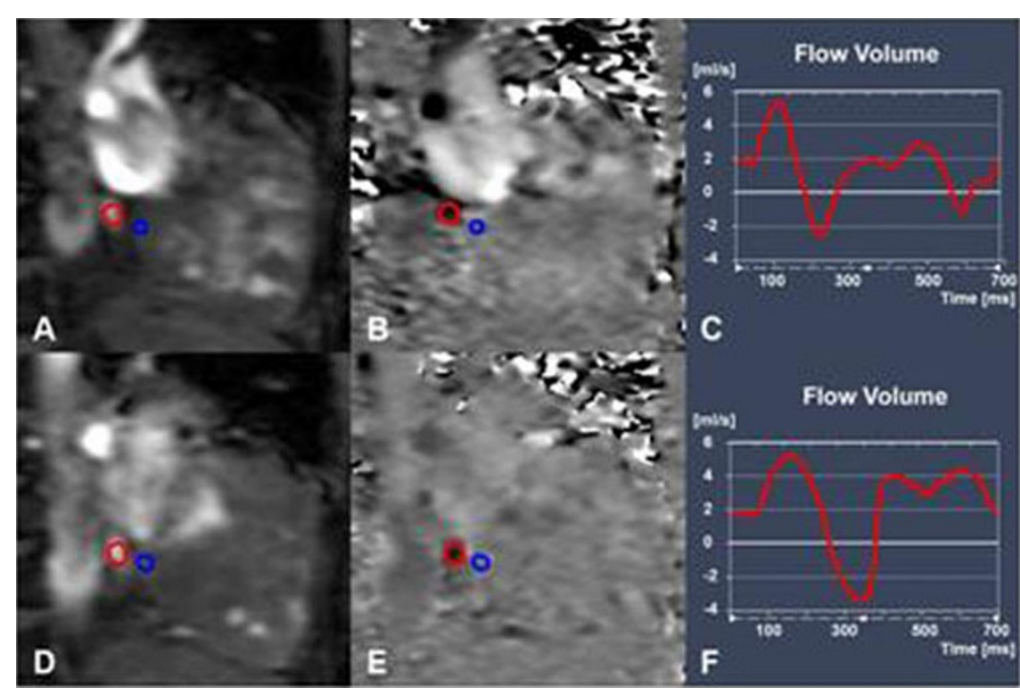

Figure $1 \mathrm{ROI}$ Placement and Flow-Time-Curves. Phase contract MRI images of the CSF for a patient with scleroderma-associated PAH (mPAP $49 \mathrm{mmHg}$ ) during rest (top row: A, B) and adenosine-induced stress (bottom row: D, E). The red ROI is drawn around the coronary sinus, the blue ROI is placed in adjacent myocardium to correct for through-plane motion. The flow-time curves (C, F) demonstrate that net CSF increased only slightly from rest $(0.86 \mathrm{ml} / \mathrm{min} / \mathrm{g})$ to stress $(1.32 \mathrm{ml} / \mathrm{min} / \mathrm{g})$, resulting in a CFR of 1.53 . Correspondingly, there is only little change in the diameter of and flow signal within the coronary sinus.

Johns Hopkins University School of Medicine, Baltimore, MD, USA

(C) 2011 Skrok et al; licensee BioMed Central Ltd. This is an open access article distributed under the terms of the Creative Commons 
Table 1 Resting and stress coronary sinus flow and coronary flow reserve

\begin{tabular}{lllll}
\hline & PAH & Non-PAH & Controls & $\mathbf{p}$ \\
\hline Rest CSF norm $(\mathrm{ml} / \mathrm{min} / \mathrm{g})$ & 0.59 & 0.55 & 0.47 & 0.42 \\
& {$[0.46-0.74]$} & {$[0.49-0.70]$} & {$[0.33-0.73]$} & \\
\hline Stress CSF $(\mathrm{ml} / \mathrm{min} / \mathrm{g})$ & 1.43 & 1.80 & 1.93 & 0.17 \\
& {$[0.58-2.00]$} & {$[1.11-2.11]$} & {$[1.38-2.17]$} & \\
\hline CFR & $2.22^{\#}$ & 2.43 & $3.93^{\#}$ & $0.008^{*}$ \\
& {$[1.40-3.22]$} & {$[1.63-4.28]$} & {$[3.07-5.01]$} & \\
\hline
\end{tabular}

(CFR) between PAH patients and healthy controls and to correlate CFR with biventricular function and pulmonary hemodynamics using magnetic resonance imaging (MRI).

\section{Methods}

Thirty-one patients with known or clinically suspected PAH underwent right heart catheterization (RHC) and 3T cardiac MRI on the same day. Twenty patients were found to have PAH, eleven patients did not have PAH. Seventeen age- and gender-matched healthy volunteers were also studied with MRI. Rest and adenosine-stress coronary sinus flow (CSF) were measured with phase contrast MRI (Figure 1) and adjusted to the biventricular mass. Resting CSF was normalized for the rate-pressureproduct $(\mathrm{RPP}=$ systolic blood pressure $\mathrm{x}$ heart rate/ 10,000; $\left.\mathrm{CSF}_{\text {norm }}=\mathrm{CSF} / \mathrm{RPP}\right)$. CFR was calculated by dividing stress CSF by resting $\mathrm{CSF}_{\text {norm }}(\mathrm{CFR}=$ Stress CSF/Rest CSF $_{\text {norm }}$ ).

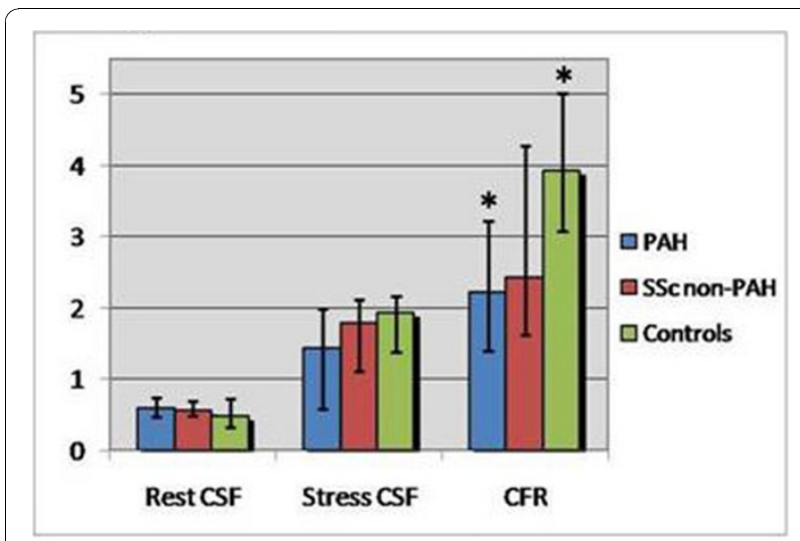

Figure 2 Resting and Stress Coronary Sinus Flow and Coronary Flow Reserve. Bar graphs demonstrate median values and $25^{\text {th }}-75^{\text {th }}$ percentiles (error bars) for resting CSF (left), stress CSF (middle) and CFR (right) for each group. Values for PAH patients are shown in blue, those for SSC non-PAH patients in red and those for the control group in green. PAH patients demonstrated a trend toward higher resting and lower stress CSF as well as a significantly lower CFR ( $\left.{ }^{*} p=0.008\right)$ compared to healthy controls. The Non-PAH group demonstrated values in-between those for PAH patients and controls.

\section{Results}

CFR for PAH patients was significantly lower $(2.22$ [1.40-3.22]) than for controls (3.93 [3.07-5.01], $\mathrm{p}=0.002)$ (Table 1, Figure 2) and was inversely correlated with mean pulmonary arterial pressure $(\mathrm{r}=-0.48, \mathrm{p}=0.03)$, pulmonary vascular resistance index $(\mathrm{r}=-0.47, \mathrm{p}=0.04)$, RV enddiastolic and end-systolic volume/BSA $(r=-0.68$, $\mathrm{p}=0.0009$ and $\mathrm{r}=-0.60, \mathrm{p}=0.005)$, RV mass $/ \mathrm{BSA}(\mathrm{r}=-0.79$, $\mathrm{p}<0.0001)$, biventricular mass/BSA $(\mathrm{r}=-0.73, \mathrm{p}=0.0002)$, and ventricular mass index $(\mathrm{r}=-0.66, \mathrm{p}=0.001)$ (Table 2$)$. On multivariate linear regression analysis, RV mass/BSA was the main predictor of CFR for PAH patients. CFR was able to distinguish between PAH patients with and without right heart failure, defined as RV CI $<2.2 \mathrm{~L} / \mathrm{min} /$ $\mathrm{m}^{2}$ (area under the ROC curve 0.81 (95\% CI: 0.55-1.00); sensitivity $83.3 \%$, specificity of $85.7 \%$ for a threshold value of 1.67).

\section{Conclusion}

PAH patients have a reduced CFR compared to healthy volunteers, which correlates with pulmonary hemodynamics and RV dysfunction. A decreased CFR is predicted

Table 2 Correlations of CFR with pulmonary hemodynamics as well as biventricular functional and structural parameters

\begin{tabular}{|c|c|c|c|c|}
\hline & \multicolumn{2}{|c|}{$\begin{array}{l}\text { PAH Patients } \\
\quad(n=20)\end{array}$} & \multicolumn{2}{|c|}{$\begin{array}{l}\text { All Patients } \\
(n=31)\end{array}$} \\
\hline & $r$ & $\mathbf{p}$ & $r$ & $\mathrm{p}$ \\
\hline Age & -0.002 & 1.0 & -0.18 & 0.35 \\
\hline Mean PAP (mmHg) & -0.48 & $0.03^{*}$ & -0.39 & $0.03^{*}$ \\
\hline Systolic PAP (mmHg) & -0.28 & 0.24 & -0.33 & 0.07 \\
\hline PVRI 9Dyne sec/ $\mathrm{cm}^{5 / \mathrm{m} 2}$ ) & -0.57 & $0.04^{*}$ & -0.37 & $0.04^{*}$ \\
\hline PCWP (mmHg) & -0.39 & 0.09 & -0.36 & $0.04^{*}$ \\
\hline RV Stroke Volume Index $\left(\mathrm{ml} / \mathrm{m}^{2}\right)$ & 0.39 & 0.09 & 0.13 & 0.50 \\
\hline Cardiac index $\left(1 / \mathrm{min} / / \mathrm{m}^{>2}\right)$ & 0.33 & 0.16 & 0.17 & 0.35 \\
\hline RV Stroke Word Index & -0.05 & 0.82 & -0.32 & 0.08 \\
\hline LV ED Volume Index $\left(\mathrm{ml} / \mathrm{m}^{2}\right)$ & 0.09 & 0.71 & -0.008 & 0.97 \\
\hline LV ES Volume Index $\left(\mathrm{ml} / \mathrm{m}^{2}\right)$ & 0.12 & 0.62 & 0.08 & 0.68 \\
\hline LV Stroke Volume Index $\left(\mathrm{ml} / \mathrm{m}^{2}\right)$ & 0.05 & 0.83 & -0.09 & 0.63 \\
\hline LV Cardiac Index $\left(1 / \mathrm{min} / / \mathrm{m}^{2}\right)$ & 0.20 & 0.39 & 0.22 & 0.23 \\
\hline LV Ejection Fraction (\%) & -0.03 & 0.89 & -0.06 & 0.74 \\
\hline LV ED Mass Index $\left(\mathrm{g} / \mathrm{m}^{2}\right)$ & -0.35 & 0.13 & -0.31 & 0.08 \\
\hline RV ED Volume Index $\left(\mathrm{ml} / \mathrm{m}^{2}\right)$ & -0.68 & $0.0009^{*}$ & -0.57 & $0.0008^{*}$ \\
\hline RV ES Volume Index $\left(\mathrm{ml} / \mathrm{m}^{2}\right)$ & -0.60 & $0.005^{*}$ & -0.55 & $0.001^{*}$ \\
\hline RV Stroke Volume Index $\left(\mathrm{ml} / \mathrm{m}^{2}\right)$ & 0.02 & 0.92 & -0.09 & 0.62 \\
\hline RV Cardiac Index $\left(\mathrm{I} / \mathrm{min} / / \mathrm{m}^{2}\right)$ & 0.17 & 0.48 & 0.18 & 0.33 \\
\hline RV Ejection Fraction & 0.43 & 0.06 & 0.36 & $0.045^{*}$ \\
\hline RV ED Mass Index $\left(\mathrm{g} / \mathrm{m}^{2}\right)$ & -0.79 & $<0.0001^{*}$ & -0.59 & $0.0004^{*}$ \\
\hline $\begin{array}{l}\text { Total Biventricular Mass } \\
\text { Index }\left(\mathrm{g} / \mathrm{m}^{2}\right)\end{array}$ & -0.73 & $0.0002^{*}$ & -0.65 & $<0.0001^{*}$ \\
\hline VMI & -0.66 & $0.001^{*}$ & -0.49 & $0.006^{*}$ \\
\hline
\end{tabular}


by RV mass and may contribute to RV failure. Further studies are warranted to investigate the predictive value of CFR with regards to patient outcome.

Published: 2 February 2011

doi:10.1186/1532-429X-13-S1-P329

Cite this article as: Skrok et al:: Coronary flow reserve correlates with right ventricular dysfunction and predicts right heart failure in patients with pulmonary arterial hypertension. Journal of Cardiovascular Magnetic Resonance 2011 13(Suppl 1):P329.

Submit your next manuscript to BioMed Central and take full advantage of:

- Convenient online submission

- Thorough peer review

- No space constraints or color figure charges

- Immediate publication on acceptance

- Inclusion in PubMed, CAS, Scopus and Google Scholar

- Research which is freely available for redistribution

Submit your manuscript at www.biomedcentral.com/submit 